\title{
DDB1 Gene
}

National Cancer Institute

\section{Source}

National Cancer Institute. DDB1 Gene. NCI Thesaurus. Code C93072.

This gene is involved in DNA repair and protein ubiquitination. 